\begin{tabular}{ccc}
\hline INESEG \\
$\begin{array}{c}\text { INTERNATIONAL } \\
\text { ENGINEERING, } \\
\text { SCIENCE AND } \\
\text { EDUCATION GROUP }\end{array}$ & e-ISSN:2618-6136 & Middle East Journal of Science \\
https://dergipark.org.tr/mejs & DO.23884/mejs.2019.5.2.04 & MEJS
\end{tabular}

Research Article

\title{
IMPROVEMENT OF SALINE HARRAN SOILS BY ELECTROKINETIC REMEDIATION
} METHOD

\author{
"Benan YAZICI-KARABULUT" ${ }^{* 1}$, Ayşe Dilek ATASOY ${ }^{2}$ iD \\ ${ }^{1}$ Harran University, Engineering Faculty, Department of Environmental Engineering, Turkey \\ ${ }^{2}$ Harran University, Engineering Faculty, Department of Environmental Engineering, Turkey \\ *Corresponding author: benanyazici@ harran.edu.tr
}

\begin{abstract}
Soil salinity has become one of the environmental issues around the world. The most typical example in Turkey was the soil salinization in Harran and Akçakale Plains in recent years. Especially the Harran Plain has the big potential of water and land resources. Irrigated farming is common in the plain. Excessive and uncontrolled irrigation contributed to the high groundwater level and soil salinity in the region. The deficiency of the drainage network in the farmlands was the most important factor in the salinity. In-field drainage systems are newly established. In some areas, irrigation is conducted through the main drainage channel with high salt content $(13.5 \mathrm{dS} / \mathrm{m})$. On the other hand, pumping irrigation waters in Akçakale region have high salt content. This problem has grown especially when dealing with low-permeable soils where conventional remedial techniques are inadequate and often ineffective. Electrokinetic treatment is an innovative and clean technology for the restoration of saline soils. This process has proven to be the most effective, promising technique for the optimal and sustainable improvement of salt-affected soils.
\end{abstract}

Keywords: Soil salinity, Harran plain, electrokinetic remediation.

Received: November 20, $2019 \quad$ Accepted: December 4, 2019

\section{Introduction}

Every year, 10 million ha of land becomes unusable due to salinity. Chlorine, sulfate, sodium, calcium, and magnesium are the main elements causing salinity, especially in arid and semi-arid climates. Especially in arid and semi-arid climatic zones, the soluble salts which are washed and mixed into the groundwater are brought to the soil surface by capillarity together with the high groundwater level and accumulation of salts occurs on the soil surface by evaporation of water [1,2]. This accumulation takes place on the soil surface or just below the surface due to the high-temperature effect. Inaccurate irrigation practices can also lead to salinity, especially in areas with poor drainage conditions [1]. 
The most typical example of the soil salinization in recent years was the Harran plain. Harran plain is a very old agricultural area and important crops have been harvested in the plain from past to present. However, some of the farmlands in the area have been turned into barren lands due to salinization. For this reason, it is very important to remediate and economically evaluate the saline soils [3].

Many conventional treatment methods for soil salinization are based on irrigation, soil deposition, salt storage plants and soil changes [4-6]. Also, oxidation, ion exchange, and precipitation, photolysis, dechlorination, soil vapor extraction, soil washing, soil flushing, soil substitution mixing and exchanging saline soil with clean soil and phytoremediation methods are used in desalination. However, some of these techniques are expensive and relatively consuming methods, requiring large quantities of cleaned water and fresh soil and they cannot remove all salts from the land [7, 8]. Although the cultivation of salt accumulating plants is temporarily effective, it only reduces the intake of salt. As a result, a large amount of salt remains in the porous medium [9]. Bioremediation and chemical restoration are less effective, time-consuming and extremely expensive [10, 11]. Recently, the Electrokinetic (EK) technique has removed salts from saline soil in a laboratory scale [12-14] and pilot-scale works [15-17]. Many studies on desalination using EK remediation have been reported [18-20]. The electrochemical treatment (ECT) is an innovative, sustainable and low-cost method that has been proven for its feasibility and potential for reclaiming low permeable saline soils [21-23]. In this study, it is tried to explain the applicability of the electrokinetic remediation method in the saline Harran Plain soils.

\section{Salinity in Harran Plain Soils}

Harran plain is the most typical example of soil salinization in recent years (Fig. 1). The area has a semi-arid climate and poorly drained soils because of the high (>60\%) clay content. Clayey soil texture has a significant risk for salinization. High clay content negatively affects the permeability of the soil and prevents the movement of water and air in the soil. Low permeability capacity increases the risk of salinization. Harran plain soils are rich in lime and potassium and are poor in nitrogen, phosphorus and organic matter. There is $24 \%$ lime in the upper soils and $26 \%$ in the lower soils. The $\mathrm{pH}$ of the soils varies between 7.5-8.0.

Soil salinity problems occurred due to excessive irrigation by farmers with little or no irrigation experience, topography, soil characteristics, climatic conditions, and insufficient drainage problems. Irrigated farming continues within the scope of GAP, 150,000 hectares of Harran plain lands. Clayey soil texture has a significant risk for salinization. Today, approximately 30,000 hectares of agricultural land in the plain have been salted and left out of production and use. The deficiency of the drainage network in the farmlands was another important factor in the salinity of soil and groundwater. Moreover, surface irrigation with these waters (saline groundwater) on heavier textured soil of the area usually leads to building up of salinity and sodicity problems and thus unsustainable crop yields. Therefore, there is a need to adopt specialized and efficient methods of irrigation like micro-irrigation which can help in attaining the twin objectives of higher productivity and optimum use of water [24]. 


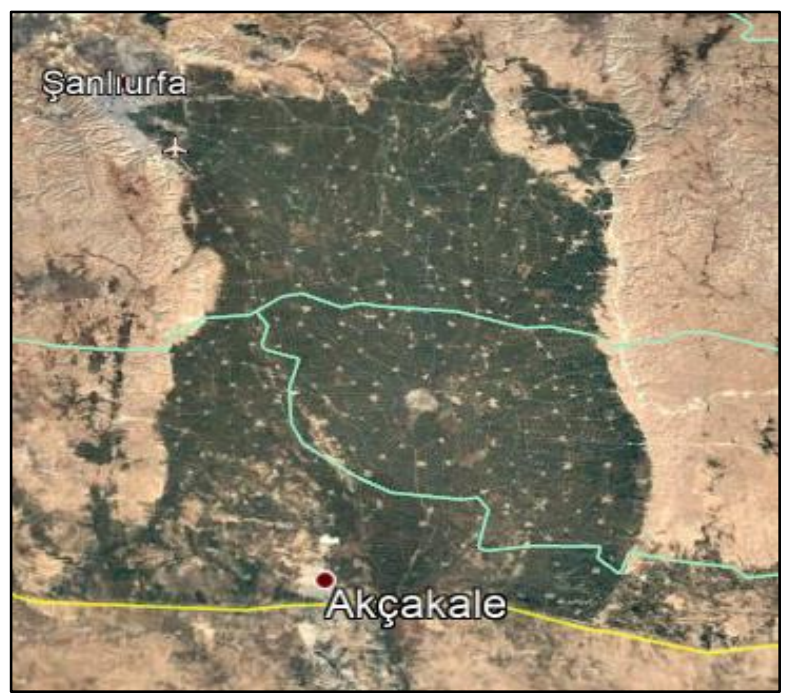

Figure 1. Location map of Harran Plain.
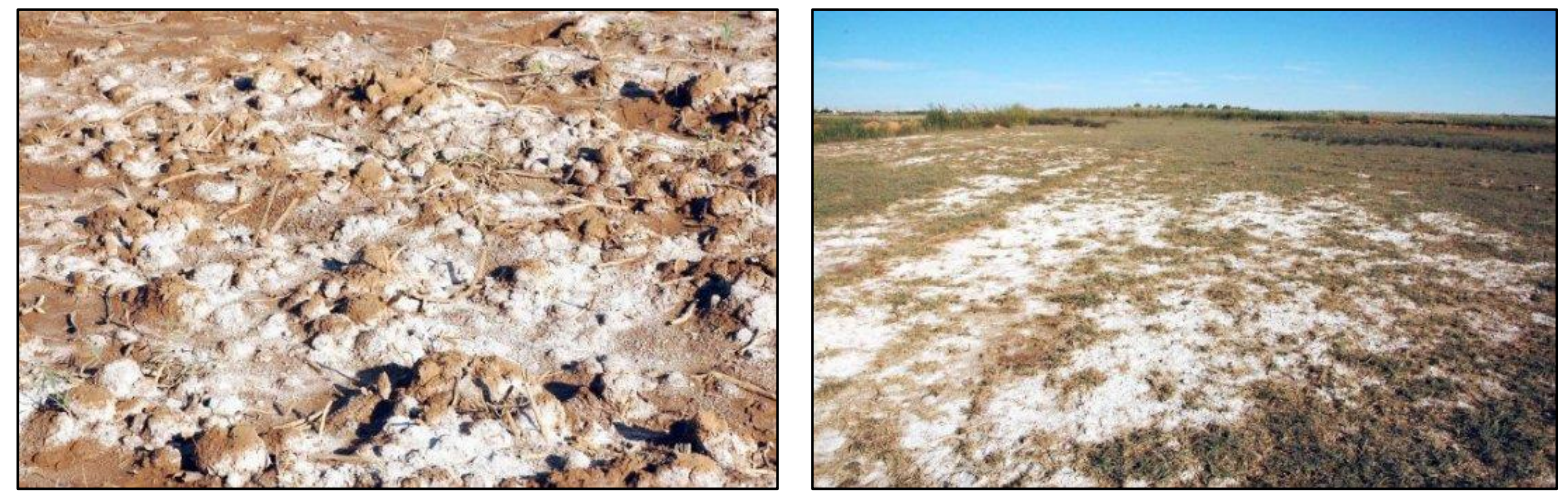

Figure 2. Salinization of agricultural lands in the area.

Salinization in the Harran plain first started with the groundwater wells drilled in Akçakale after 1970. These wells drilled by the State Hydraulic Works in Akçakale supplied water from the groundwater due to the cheap cost. Saline groundwater in shallow depth occurred due to insufficient drainage network and saline soils began to form over time (Fig. 2). The amount of salinity increased due to drainage problems after 1995 starting irrigated farming. The salinization on the South of Harran plain has reached serious dimensions due to insufficient underground and surface drainage. The area of saline soils will increase in the near future unless the necessary rehabilitation works are carried out.

\section{Electrokinetic Remediation Methods}

Soil salinity can be represented by the high electrical conductivity (EC, dS/m) of the soil. Electrokinetic (EK) remediation has considerable potential for the decontamination of saline soils with low permeability. EK remediation technology is an innovative, sustainable and low-cost method used for the stabilization and restoration of saline soils [25-27]. The major advantage of the method is that it is cost-effective for both in-situ and ex-situ treatment (Fig. 3). 


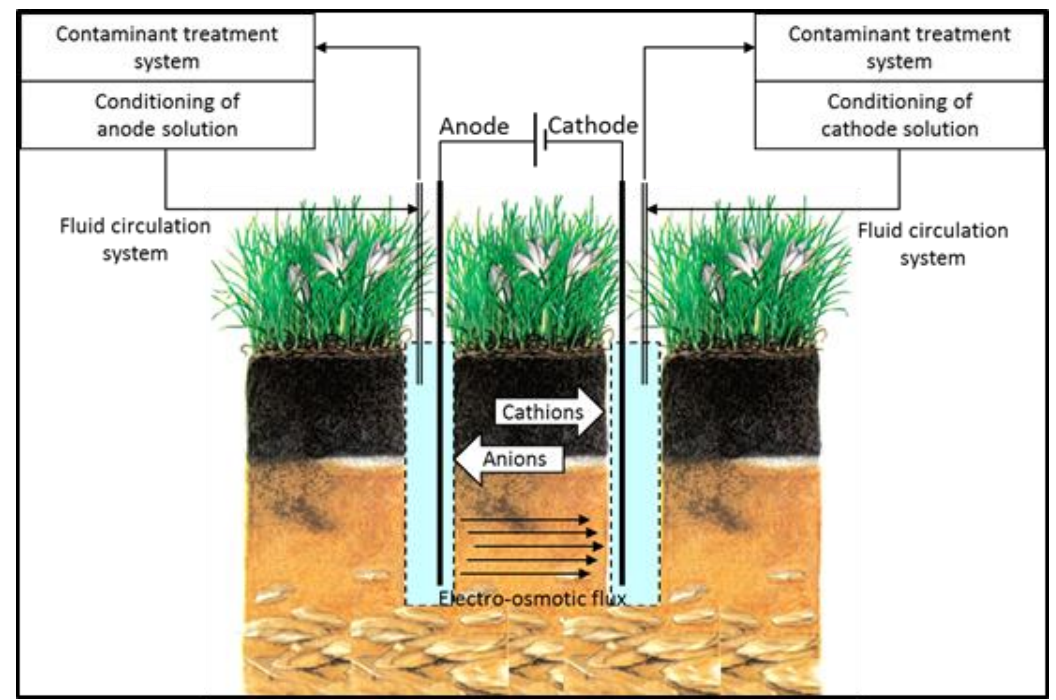

Figure 3. Application of the electrokinetic remediation in a contaminated site [28].

Soil salinity problems are very common in arid and semi-arid regions. Most of the cultivation activities of salt-affected soils are partly or totally unsuccessful. These failures are often due to the lack of appropriate diagnosis and the subsequent use of incorrect irrigation methods. This leads to the loss of both money and potential crop production. But the electrokinetic remediation process is the most promising, inexpensive and easily applicable green technology for the treatment of saline soils.

Electrokinetic treatment technologies basically work as a simple battery assembly. Accordingly, a series of electrodes (lead, copper, zinc, graphite, titanium, etc.) are connected to the contaminated zone and a certain amount of direct current is supplied to these electrodes. Due to the electrical current given to the electrical load in the ground a movement occurs towards the reverse charged electrode through the pollutants by electromigration, electro-osmosis, electrolysis, and diffusion. [29-31] (Fig. 4). The contaminant coming to the reverse charged electrode is deposited on the electrode, depending on its type and preference, or transported to the surface by the pump assembly and treated there. Recently, the EK remediation technique has been used for the recovery and reuse of saline soils. Tab.1. showed EK remediation studies in literature.

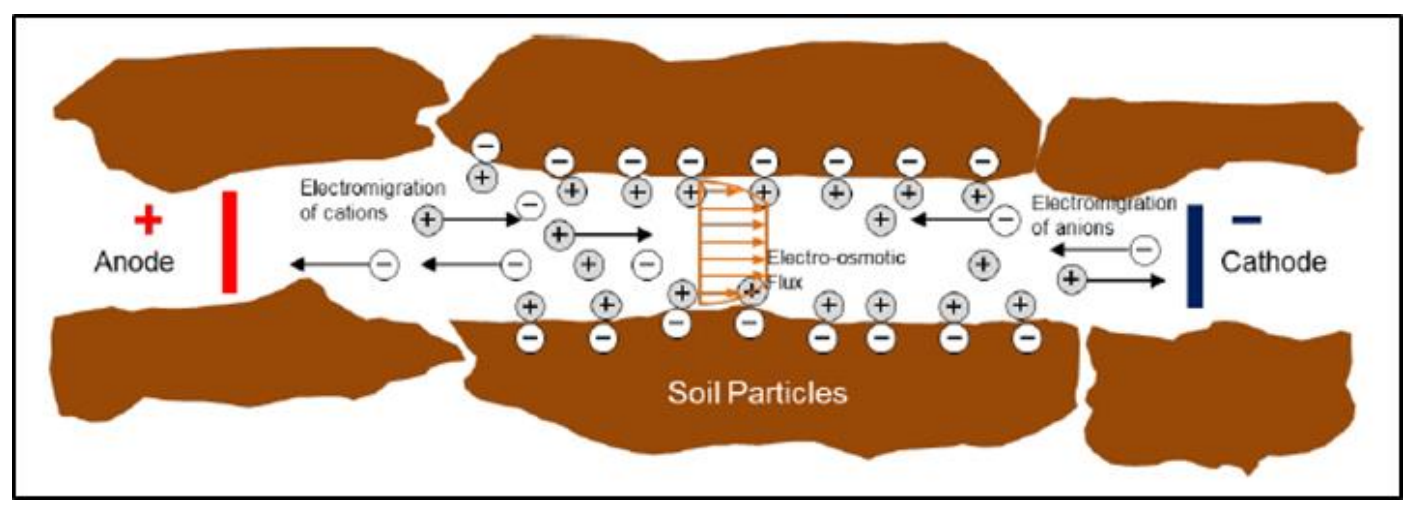

Figure 4. Transport mechanism of electrokinetic restoration [29]. 
Table 1. EK remediation studies in literatures.

\begin{tabular}{|c|c|c|}
\hline Reference & Region & Efficiency/feasibility \\
\hline [8] & $\begin{array}{l}\text { Saline greenhouse soil } \\
\text { at Gumi, Gyeongbuk, } \\
\text { Republic of Korea. Surface } \\
\text { soil }(0-20 \mathrm{~cm}) .\end{array}$ & $\begin{array}{l}\text { EK system could lower the corrosion rate of an } \\
\text { electrode by approximately } 38 \% \text { and reduce electrical } \\
\text { energy consumption by approximately } 60 \% \text { compared } \\
\text { to the DC system, which would allow for longer } \\
\text { application in the field. }\end{array}$ \\
\hline [9] & $\begin{array}{l}\text { An actual greenhouse in } \\
\text { Gumi, Korea. Surface soil }(0- \\
20 \mathrm{~cm}) .\end{array}$ & $\begin{array}{l}\text { The pulsed electrokinetic process lowered the } \\
\text { electrical energy consumption to } 42 \% \text { of that of the } \\
\text { conventional process }\end{array}$ \\
\hline$[16]$ & $\begin{array}{l}\text { Surface saline soil }(0-25 \mathrm{~cm}) \\
\text { was sampled from a } \\
\text { greenhouse at Gumi, South } \\
\text { Korea. }\end{array}$ & $\begin{array}{l}\text { EK treatment resulted in the removal of approximately } \\
30 \% \text { of } \mathrm{K} \text { and } \mathrm{Ca} \text { from the system. }\end{array}$ \\
\hline [32] & $\begin{array}{l}\text { Dakhla Oasis, central } \\
\text { Western Desert of Egypt. } \\
\text { Surface soil }(0-20 \mathrm{~cm})\end{array}$ & $\begin{array}{l}\text { Linear spectral unmixing (LSU) proved to predict } \\
\text { salinity more accurately with } 76 \% \text { correctness than } \\
\text { mixture tuned matched filtering (MTMF) model } \\
(67 \%) \text { and the band combination and spectral indices } \\
(55 \% \text { at most). }\end{array}$ \\
\hline [33] & $\begin{array}{l}\text { North-west of Algeria, in the } \\
\text { lower valleys of West } \\
\text { Mostaganem, especially in } \\
\text { the region of Ain Nouissy. }\end{array}$ & $\begin{array}{l}\text { The proposed technique achieved removal rates of } \\
83 \% \text { and } 58 \% \text { for sodium and calcium ions } \\
\text { respectively after } 15 \text { days of EK treatment. }\end{array}$ \\
\hline
\end{tabular}

\section{Electrode Materials and Configuration}

Fig. 5 shows a schematic of the EK remediation system. Soil compartments are placed between electrode chambers and are filled with compacted saline soil. Electrode compartments acted as overflow systems. The EK process involves direct application of a low voltage gradient or electrical current to polluted soil through installed electrodes as anode and cathode (graphite, platinum, etc). Salts, which have high water solubility and exist as charged ions, are transported and removed by electromigration (movement of charged ions), electro-osmosis (liquid flow from anode to the cathode through the pore spaces between particles), and electrophoresis (transfer of charged particles) from the soil surface. 


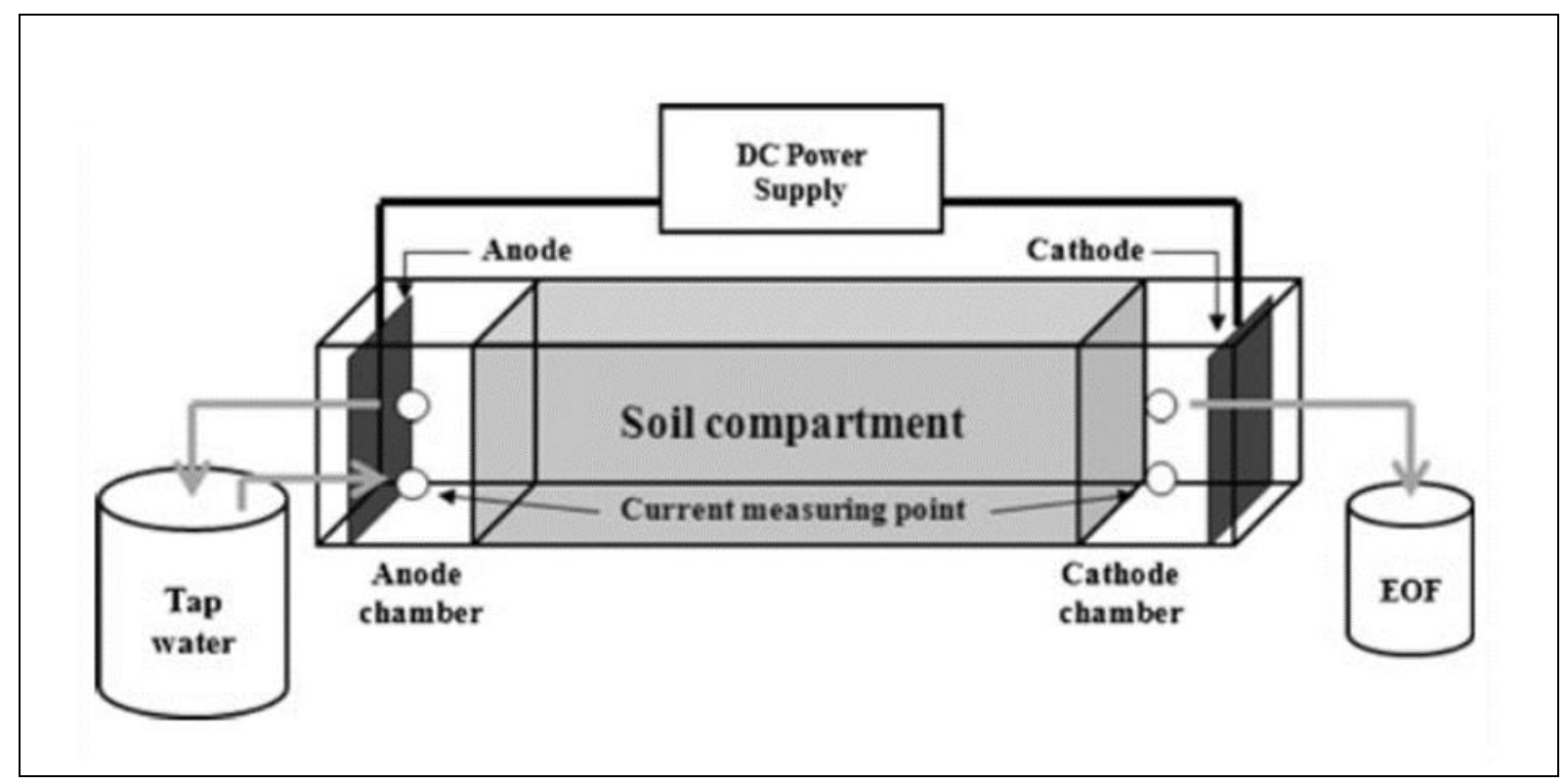

Figure 5. Schematic of an EK remediation system [7].

\section{Applicability and Limitations of EK Remediation}

Electrokinetic (EK) remediation technology has a significant potential for the cultivation of crops on saline soils (such as clay) with low permeability. This technology is an innovative, sustainable and inexpensive method proposed for the stabilization and reuse of soils in general and especially fine grains. EK remediation involves applying the electric current directly to the contaminated soil with a low voltage gradient or electrodes placed in the soil [33].

Long-term EK applications require a low voltage gradient because the property of the earth may be affected by the EK process under a high voltage gradient and may consume a lot of electricity [7]. In situ and ex situ applications of EK remediation have been developed [34]. The EK technique can be applied to widely dispersed pollutants in soils containing clay or sand in both unsaturated and saturated regions. The EC can remove polar and / or water-soluble organic compounds such as contaminants, heavy metals, arsenic, nitrates, phosphates, halogenides and cyanides, phenols and nitro aromatics (such as TNT).

\section{Conclusion}

As a result, the salinity problem is an important issue in the Harran Plain in Sanliurfa due to the high groundwater levels. In recent years, agricultural lands in this region have become impracticable and unusable. Electrokinetic treatment is an un-attempt, innovative and clean technology for the restoration of saline soils for this region. This process is thought to be the most effective, promising technique for the optimal and sustainable improvement of salt-affected soils in the Harran plain.

\section{References}

[1] Ergene, A., “'Toprak Bilgisi”, Atatürk Üniversitesi Ziraat Fakültesi Yayınlarl, Erzurum, 1982.

[2] Kwiatowsky, J., "Salinity Classification, Mapping and Management in Alberta", Food and Rural Development and Agriculture and Agri-food, Canada, 1998. 
[3] Woods, S.A., "Salinity Tolerance of Ornamental Trees and Shrubs", Food and Rural Development and Agriculture and Agri-food, Canada, 1996.

[4] Kim, K.J., Cho, J.M., Baek, K., Yang, J.S., Ko, S.H., “'Electrokinetic removal of chloride and sodium from tidelands", Journal of Applied Electrochemistry, 40, 1139-1144, 2010.

[5] Choi, J.H., Lee, Y.J., Lee, H.G., Ha, T.H., Bae, J.H., “ 'Removal characteristics of salts of greenhouse in field test by in situ electrokinetic process", Electrochimica Acta, 86, 63-71, 2012.

[6] Jo, S., Shin, Y.J., Yang, J.S., Moon, D.H., Koutsospyros, A., Baek, K., "'Enhanced electrokinetic transport of sulfate in saline soil', Water Air Soil Pollution, 226, 199, 2015.

[7] Cho, J., Park, S., Baek, K., "Electrokinetic restoration of saline agricultural lands', Journal of Applied Electrochemistry, 40, 1085-1093, 2010.

[8] Kim, D.H., Jo, S.U., Yoo, J.C., Baek, K., “Ex situ pilot scale electrokinetic restoration of saline soil using pulsed current", Separation and Purification Technology, 120, 282-288, 2013.

[9] Jo, S.U., Kim, D.H., Yang, J.S., Baek, K., "Pulse-enhanced electrokinetic restoration of sulfatecontaining saline greenhouse soil", Electrochimica Acta, 86, 57-62, 2012.

[10] Reddy, K.R., Shirani, A.B., "Electrokinetic remediation of metal contaminated glacial tills", Geotechnical and Geological Engineering, 15, 3-29, 1997.

[11] Kharayat, Y., "Distillery wastewater: bioremediation approaches", Journal of Integrative Environmental Sciences, 9, 69-91, 2012.

[12] Cho, J.M., Kim, D.-H., Yang, J.S., Baek, K. “Electrode configuration for electrokinetic restoration of greenhouse saline soil', Separation Science and Technology, 47, 1677-1681, 2012.

[13] Cho, J.M., Kim, D.-H., Yang, J.S., Baek, K., "Electrokinetic restoration of sulfate accumulated saline greenhouse soil', Clean-Soil Air Water, 9, 1036-1040, 2011.

[14] Jia, X., Larson, D., Slack, D., Walworth, J., "Electrokinetic control of nitrate movement in soil', Engineering Geology, 77, 273-283, 2005.

[15] Kim, D.H., Cho, J.M., Baek, K., 'Pilot-scale ex situ electrokinetic restoration of saline greenhouse soil', Journal of Soils and Sediments, 11, 947-958, 2011.

[16] Kim, D.H., Jo, S.U., Choi, J.H., Yang, J.S., Baek, K., “Hexagonal two-dimensional electrokinetic systems for restoration of saline agricultural lands: a pilot study', Chemical Engineering Journal, 198-199, 110-121, 2012.

[17] Lee, Y.J., Choi, J.H., Lee, H.G., Ha, T.H., Bae, J.H., "'Pilot-scale study on in situ electrokinetic removal of nitrate from greenhouse soil ', Separation Science and Technology, 79, 254-263, 2011.

[18] Manokararajah K, Ranjan R.S., " Electrokinetic retention, migration and remediation of nitrates in silty loam under hydraulic gradients", Engineering Geology, 77, 263-272, 2005.

[19] Jia, X., Larson, D.L., Zimmt, W.S., 'Effective nitrate control with electrokinetics in sand soil”, Transactions of the ASABE, 49, 803-809, 2006.

[20] Eid N, Elshorbagy W, Larson D, Slack D., "Electro-migration of nitrate in sandy soil", Journal of Hazardous Materials, 79, 133-149, 2000.

[21] Yola, M.L., Eren, T., İlkimen, H., Atar, N., Yenikaya, C., “A sensitive voltammetric sensor for determination of Cd (II) in human plasma', Journal of Molecular Liquids, 197, 58-64, 2014.

[22] Göde, C., Yola, M.L., Yılmaz, A., Atar, N., Wang, S., “A novel electrochemical sensor based on calixarene functionalized reduced graphene oxide: application to simultaneous determination of Fe(III), Cd (II) and Pb(II) ions', Journal of Colloid and Interface Science, 508, 525-531, 2017. 
[23] Faisal, A.A.H., Sulaymon, A.H., Khaliefa, Q.M., “A review of permeable reactive barrier as passive sustainable technology for groundwater remediation", International Journal of Environmental Science and Technology, 15, 1123-1138, 2018.

[24] Atasoy, A.D., Yesilnacar, M.İ., "Groundwater pollution due to agricultural practices in a semiarid area', In: Water Recycling and Water Management (Ed. D.M. Carrey), Nova Science Publishers, Inc., 2010.

[25] Klouche, F., Bendani, K., Benamar, A., Missoum, H., Laredj, N., "Remediation of the saline soil of the Mostaganem region by electrokinetic technique', Innovative Infrastructure Solutions, 3, 73, 2018.

[26] Cho, J.M., Kim, K.J., Chung, K.Y., Hyun, S.H., Baek, K., “'Restoration of saline soil in cultivated land using electrokinetic process", Separation Science and Technology, 44, 2371-2384, 2009.

[27] López-Vizcaíno, R., Yustres, A., León, M.J., Saez, C., Cañizares, P., Rodrigo, M.A., Navarro, V., "Multiphysics implementation of electrokinetic remediation models for natural soils and porewaters", Electrochimica Acta, 225, 93-104, 2017.

[28] Cameselle, C., Gouveia, S., Akretche, D.E., Belhadj, B., “Advances in Electrokinetic Remediation for the Removal of Organic Contaminants in Soils", (Ed. M.N. Rashed), Organic PollutantsMonitoring, Risk and Treatment, 2013.

[29] Baek, K., Kim, D.H., Park, S.W., Ryu, B.G., Bajargal, T., Yang, J.S., “Electrolyte conditioningenhanced electrokinetic remediation of arsenic-contaminated mine tailing", Journal of Hazardous Materials, 161, 457-462, 2009.

[30] Eykholt, G.R., Daniel, D.E., "Impact of system chemistry on electroosmosis in contaminated soil", Journal of Geotechnical Engineering, 120, 797-815, 1994.

[31] Kim, D.H., Jeon, C.S., Baek, K., Ko, S.H., Yang, J.S. "Electrokinetic remediation of fluorinecontaminated soil: conditioning of anolyte”, Journal of Hazardous Materials, 161, 565-569, 2009.

[32] Masouda, A.A., Koike, K., Atwia, M.G., El-Horiny, M.M., Gemail, K.S. “Mapping soil salinity using spectral mixture analysis of landsat 8 OLI images to identify factors influencing salinization in an arid region", International Journal of Applied Earth Observation and Geoinformation, Vol.83, pp.101944, 2019.

[33] Klouche, F., Bendani, K., Benamar, A., Missoum, H., Maliki, M., Laredj, N., “Electrokinetic restoration of local saline soil', Materials Today, in press.

[34] Hamdan, S.H., Molelekwa, G.F., Van der Bruggen, B., “'Electrokinetic remediation technique: an integrated approach to finding new strategies for restoration of saline soil and to control seawater intrusion', ChemElectroChem, Vol.1, pp.1104-1117, 2014. 